Matgorzata Perechowska

Maria Kowalik*

Włocławek

\title{
Odkrywanie wartości przez uczniów gimnazjum - uwagi katechetyczne
}

\author{
Żaden promień światta nie jest daremny, \\ lecz ziarno, które pod jego wptywem kiełkuje, \\ potrzebuje czasu, aby wzejść. \\ Nie zawsze siewca może uczestniczyć w plonach. \\ Każde wartościowe dzieło jest owocem wiary
}

(Albert Schweitzer)

\section{Wprowadzenie}

Ujmując ogólnie treści katechez w gimnazjum można powiedzieć, że dotyczą one: prawd filozoficznych, świata wartości - ogólnoludzkich i chrześcijańskich; Pisma Świętego; Sakramentów; Boga; darów Ducha Świętego; rodziny. Z jednej strony zauważamy w uczniach wrażliwość na świat wartości, i jednocześnie czas buntu, nietolerancji, niezgadzania się na to, co jest $\mathrm{w}$ rodzinie, w szkole. $\mathrm{Z}$ drugiej strony zaniepokoił nas fakt, że treści niektórych katechez gimnazjalnych szczególnie z zakresu świata wartości, są jakby nad „głowami uczniów”. Młodzież poszukuje wartości, wydaje się, że je rozumie, ale nie stosuje w życiu. Przykłady:

- uczeń po przyjęciu sakramentu bierzmowania rezygnuje z uczestnictwa w lekcji religii. Przez trzy lata przygotowywał się do tego sakramentu, deklarował głośno ważność i niezbędność Kościoła, przyjmował i realizował postawione wymagania.

* S. dr Małgorzata Perechowska, wykładowca w Instytucie Teologii we Włocławku, katechetka w Gimnazjum nr 2 we Włocławku. S. mgr Maria Kowalik katechetka, obecnie wychowawczyni w Internacie ZSK im. Jana Długosza we Włocławku. 
Po otrzymaniu „dokumentu” odrzuca to, co - jak się wydawało - było dla niego ważne. Jego rodzice tłumaczą, że jest już na tyle dorosły, że może sam wybierać;

- są dziewczęta, które nie tolerują ordynarnego zachowania, ale akceptują je, ponieważ grupa przyjmująca taką postawę jest dominująca, a one nie chcą zostać same. Utożsamiają się z rówieśnikami, by być jednymi z tych, o których się mówi - „są fajne”;

- kształtowanie u młodzieży prawego sumienia, poszukiwanie wartości, staje się bardziej pragnieniem katechety, niż pragnieniem młodego człowieka. Młodzież napotyka trudności w rozwoju moralnym, bo praca nad sobą nad kształtowaniem prawidłowego sumienia zaczyna się $\mathrm{w}$ domu, a religijne wychowanie $\mathrm{w}$ domu przeżywa dziś kryzys;

- obserwujemy spadek liczby osób uczestniczących we mszach św. w niedzielę, przy utrzymującej się liczbie osób komunikujących. Mamy więc jednocześnie do czynienia z zanikaniem wrażliwości na grzech.

Aby lepiej zrozumieć, przed jakimi trudnościami staje katecheza w gimnazjum, przedstawimy krótką charakterystykę młodzieży okresu dorastania i stosunek młodych ludzi w tym wieku wobec poznawanych wartości ogólnoludzkich i chrześcijańskich. W tym krótkim artykule, opartym głównie o doświadczenie kontaktu katechetycznego z młodzieża, pragniemy zastanowić się jakie są drogi odkrywania wartości przez uczniów gimnazjum. Będą to głównie uwagi katechetyczne.

\section{Ogólna charakterystyka wieku dorastania i etapy ksztaltowania stosunku do wartości}

W naukach medycznych okres biologicznych przemian nosi nazwę „dojrzewania", natomiast w psychologii polskiej najczęściej stosuje się nazwę ,wiek dorastania". Obejmuje on okres od ok. 11-12 r.ż. do około 18-19 r.ż'. W okresie dorastania człowiek uzyskuje zdolność do dawania nowego życia, jak i zdolność do samodzielnego kształtowania własnego życia. Tworzy się coraz większa rozbieżność między dojrzewaniem biologicznym a dojrzewaniem psychicznym i społecznym. Fazy te częściowo nachodzą na siebie. Około 16 r. ż. występuje tzw. kryzys młodzieńczy, charakteryzujący się nasileniem psychicznych trudności dorastania. To, w jaki sposób młody człowiek będzie starał się pokonywać kryzys i pojawiający się problem własnej tożsamości, determinuje w znacznym stopniu jego dalszy rozwój psychiczny.

Pierwsza faza dorastania, bardziej biologiczna, charakteryzuje się ogólnym niezrównoważeniem emocjonalnym, wyrażonym w nadmiernej pobudliwości. Młodzież już nie przyjmuje bezkrytycznie informacji o świecie zewnętrznym, ale wnikliwie je rozważa, ocenia i selekcjonuje. Występujący u młodych ludzi wzrost krytycyzmu nie wynika z niechęci do dorosłych ani ze złej woli samych dorastających. Przyczynia się do tego rozwój intelektualny i uczuciowy.

${ }^{1}$ I. Obuchowska, Drogi dorastania. Psychologia rozwojowa okresu dorastania dla rodziców i wychowawców, Warszawa 1996, s. 9. 
W tym czasie, na bazie wiedzy i zdobywanych umiejętności następuje utrwalenie zachowań i postaw osobowych, które podkreślają wartości etyczne i estetyczne. Wartości są to dobra, które stanowią cel ludzkich dążeń, których respektowanie decyduje o tym, że postępowanie człowieka jest dobre. Na tym etapie uczeń staje gotowy do spotkania z wartością².

Młodzież znajduje się w stanie wewnętrznego konfliktu między potrzebą bycia dorosłym i samodzielnym a zachowaniem przywilejów dziecka. Poszukuje ona własnej tożsamości, jest w niej potrzeba bycia sobą. Poczucie odrębności miesza się z uległością, konformizmem, potrzeba autorytetu z jego odrzuceniem, a potrzeba wzorów ze stopniowym zmniejszaniem się ich wpływów.

$\mathrm{Na}$ tym etapie uczeń styka się z wartościami, spostrzega je, choć z powodu chwiejności uczuciowej nie jest jeszcze w stanie wprost opowiedzieć się za tym, co jest bezsprzecznie pozytywne ${ }^{3}$.

Druga faza dorastania, rozpoczynająca się zazwyczaj po 16 r.ż., charakteryzuje się poszukiwaniem wyjścia $\mathrm{z}$ chaosu przeżyć i działań, stopniowym porządkowaniem, stawianiem sobie celów i dostosowaniem do nich swojego postępowania ${ }^{4}$. W tej fazie dominującą rolę odgrywają procesy intelektualne, procesy biologiczne są już z reguły ustabilizowane.

W czasie tego procesu rozwojowego, uczeń przypisuje znak dodatni poznanym obiektom, przedmiotom, sądom, zachowaniom. Uczeń uznaje wartośćs.

Poszukiwanie własnej tożsamości staje się coraz bardziej świadome, poparte refleksją i werbalizowane. Młodzież stawia sobie pytania egzystencjalne dotyczące sensu życia i śmierci. Zagadnienie sensu życia u młodzieży zdominowane jest przez aktualne problemy ogólnoludzkie - problemy wojny i pokoju, wolności i zniewolenia, katastrofy ekologicznej, stabilizacji społecznej i kryzysów. Niekiedy pojawia się lęk przed przyszłością. Niektórzy młodzi ludzie odrzucają dorosłość i nie chcą się do niej przygotować. Większość młodych jednak przygotowuje się do ponoszenia odpowiedzialności i działań związanych z dorosłością.

Podczas powyższych procesów wartości nabierają siły i znaczenia dla konkretnego ucznia. Młody człowiek porównuje wartości, zestawia i wybiera. Często wyborom wartości towarzyszą odczucia emocjonalne. Wówczas spostrzeżenia przemawiające przeciwko wartości bywają odbierane jako przykrość, a czasem nawet są odrzucane. Połączenie intelektu z emocjami pozytywnymi wpływa na głębsze utożsamienie się $\mathrm{z}$ wartością. Jest to etap, kiedy uczeń czuje się związany z wartością̧.

Zarówno pierwsza, jak i druga faza okresu dorastania może mieć różny przebieg: - może być długotrwała i głęboka, bądź krótkotrwała i zawężona do pojedynczych pytań egzystencjalnych.

\footnotetext{
${ }^{2}$ K. Kruszewski, Sztuka nauczania. Czynności nauczyciela, Warszawa 1998, s. 159.

${ }^{3}$ Tamże, s. 160.

${ }^{4}$ I. Obuchowska, Drogi dorastania..., s. 14.

${ }^{5}$ K. Kruszewski, Sztuka nauczania..., s. 161.

${ }^{6}$ Tamże, s. 162.
} 
W najwyższym etapie odkrywania wartości przez gimnazjalistów, może dochodzić do uogólnienia wartości. Uczeń wtedy potrafi oderwać wartość od konkretnej sytuacji, od jej nośnika. Wartość staje się ważna sama w sobie.

Dalsze etapy życia przy sprzyjających warunkach powinny doprowadzić do:

- tworzenia uwewnętrznionego systemu wartości. Wówczas dana wartość wchodzi w związki z innymi wartościami, zajmuje swoje miejsce w hierarchii. Mówi się wówczas, że uczeń zasymilował wartość;

- podporządkowania działania wartościom. Znakiem tej przemiany jest zachowanie ucznia zgodnie z uznawaną przez niego wartością. Uczeń działa według wartości;

- ukształtowanie światopoglądu. Jeżeli dana wartość harmonizuje z innymi, może wejść w światopogląd ucznia. Uczeń w pełni włączył wartość w swój system przekonań, myślenia i działania ${ }^{7}$.

Z obserwacji wynika jednak, iż wyliczone powyżej procesy odkrywania wartości przenoszą się na kolejne etapy życia, poza czas gimnazjum. Uczeń jakby z natury nie jest ich w stanie sobie przyswoić, co najwyżej na płaszczyźnie intelektu.

Aby bardziej świadomie kształtować postawy moralne, których podstawą są wartości, należy też poznać prawidłowości i etapy rozwoju moralnego.

\section{Rozwój moralny}

Dorastanie jest okresem intensywnego rozwoju moralnego. Wzrasta zainteresowanie problemami natury moralnej, moralne ocenianie cudzego i własnego postępowania. Badaniami nad rozwojem moralnym zajmował się Jean Piaget, który stworzył model czterostadialny. Opierając się na jego pracach i własnych badaniach Lawrence Kohlberg opracował model rozwoju rozumowania moralnego. Przebiega on przez trzy poziomy, na których wyróżnia się po dwa stadia.

Poziom I - przedkonwecjonalny

Stadium 1. Moralność heteronomiczna („Moralność wywodzi się z władzy i autorytetu")

Stadium 2. Indywidualizm i cele instrumentalne („Moralność to troszczenie się o siebie samego")

Poziom II - konwencjonalny

Stadium 3. Konformizm interpersonalny („Moralność oznacza robienie tego, za co jest się lubianym")

Stadium 4. Prawo i porządek („Dozwolone jest to, co jest zgodne z prawem”)

Poziom III - pokonwencjonalny

Stadium 5. Społeczny kontakt („Prawa człowieka są ważniejsze od innych praw”)

Stadium 6. Uniwersalne zasady etyczne („Moralność jest sprawą własnego sumienia") $)^{8}$.

\footnotetext{
${ }^{7}$ Tamże, s. 163.

${ }^{8}$ R. Vasta, M. M. Haith, S. A. Miller, Psychologia dziecka, Warszawa 1995, s. 484-486.
} 
Dziecko znajdujące się w stadium pierwszym jest egocentryczne. Podejmuje działania wyłącznie dlatego, że się boi. Również drugie stadium jest namiastką rozwoju moralnego. Przy wyborze działania dominuje wyłącznie egoizm. Zachowanie moralne jest spostrzegane jako wartościowe, jeśli służy interesom dziecka. Dzieci przestrzegają zasad mając na uwadze to, co otrzymają w zamian - ,ja tobie daję to i ty musisz mi coś dać".

W psychologii przyjmuje się, że poziom konwencjonalny przypada na wczesny okres dorastania. Stadium trzecie jest próbą otarcia się o początek prawdziwego rozwoju moralnego. Właściwe zachowanie to takie, które większość ludzi uważa za właściwe. Osoba chce być zauważona jako czyniąca dobro i przez to akceptowana przez otoczenie, zwłaszcza rówieśników. Dobro więc jest tylko środkiem a nie celem postępowania. Czwarty poziom według L. Kohlberga stanowi barierę, na której wiele osób kończy swój rozwój. W tym stadium moralność opiera się na ścisłym przestrzeganiu praw i wywiązywaniu się z obowiązków. Zasady są postrzegane jako najlepsze środki rozwiązywania interpersonalnych konfliktów. Człowiek zaprzestaje dalszych poszukiwań wzrostu moralnego, zadowala się przyjęciem i przestrzeganiem danego prawa jako utartych norm moralnych. Osoba ślepo wierzy w prawo i nie ma zamiaru czynić niczego, co by poza to prawo wychodziło.

Tak naprawdę dopiero od piątego stadium możemy mówić o pełnym rozwoju moralnym człowieka. Człowiek zaczyna dostrzegać, że istnieje coś więcej niż prawo. Widzi on, że prawo nie w każdej sytuacji daje możliwość poprawnego wyboru. Różnica między poprzednim stadium polega nie na absolutyzowaniu prawa, ale na możliwościach jego zmiany w konkretnych sytuacjach. Moralność opiera się na obronie indywidualnych praw człowieka. W szóstym stadium przyjmuje się, że istnieją uniwersalne zasady moralne, które znajdują się ponad prawem, na przykład: sprawiedliwość i poszanowanie godności człowieka. Człowiek poszukuje własnych wartości, na których pragnie oprzeć swoje życie. Fundamentem dla tego stadium jest kształtowanie w odpowiedni sposób własnego sumienia.

Należy także dodać, że L. Kohlberg pod koniec swojego życia, teorię poziomu moralnego wzbogacił o stadium siódme, doskonałości moralnej, do jakiej może dojść człowiek. Na rozwój tego siódmego stopnia rozwoju moralnego miał wpływ jego zachwyt nad wiarą, Kościołem i katolicyzmem. Ów siódmy stopień jest nie do końca wynikiem pracy człowieka. Konieczne jest otwarcie się na działanie łaski Bożej, która przemienia człowieka. Został on nazwany przez L. Kohlberga poziomem agape, błędnie czasem tłumaczonej na język polski stadium kosmicznym 9 .

Obserwacja rozwoju moralnego gimnazjalistów wskazywałaby, że znajdują się oni w większości przypadków w trzecim stadium rozwoju, zaś niewielka liczba osób w czwartym stadium. Jak więc należałoby przedstawiać gimnazjalistom świat wartości ogólnoludzkich i chrześcijańskich, skoro oni w swoim etapie rozwoju dochodzą do uogólniania wartości, a nie mają jeszcze, albo nie są w stanie tworzyć własnego systemu wartości?

${ }^{9}$ J. T. Granatowski SJ, Teoria Kohlberga, „Być dla innych”, Biuletyn metodyczny dla nauczycieli, 2001, nr 9. 
Jak kształtować postawę, opartą na zasadach, że „prawa człowieka są ważniejsze od innych praw” i „moralność jest sprawą własnego sumienia” (stadium piąte i szóste według Kohlberga), skoro ta grupa wiekowa jest na etapie trzecim? A przecież żadnego etapu rozwoju rozumowania moralnego nie można pominąć.

Co w tej zawiłej sytuacji proponuje nam podręcznik do kl. I, II, III gimnazjum, pod redakcją Danuty Jackowiak i ks. Jana Szpeta ${ }^{10}$. Autorzy tego podręcznika proponują świat wartości przedstawić w formie definicji, myśli filozoficznych, obrazów z życia, czy też przyrody. Sam podręcznik jest ciekawy, ale po głębszej analizie trochę górnolotny. Trudno jest przyjać gimnazjalistom teoretyczne wykłady o wartościach i w dodatku podanych w odległym dla nich języku filozofii i definicji. Brakuje w nim konkretnych przykładów z życia i propozycji metod właściwych do odkrywania wartości. Na braki te wskazują również wypowiedzi gimnazjalistów klas drugich: „,zrozumieć temat pomagają mi definicje, obrazki, różne wykresy, a także punkt »zatrzymaj się«. Brakuje mi opowiadań przełożonych na życie codzienne, gdyż w ten sposób łatwiej byłoby mi przyswajać tematy. Brakuje mi także różnych wypowiedzi, tych ludzi, którzy na swój sposób rozumieją dany temat, co o nim sądzą i myślą”; ,chciałbym, aby na katechezie poruszane były tematy egzystencjalne (obojętnie jakie), ponieważ miałbym zawsze coś do powiedzenia”; „brakuje mi wypowiedzi innych dzieci, młodzieży i dorosłych”; „,na katechezie powinny poruszane być tematy życiowe, również opowieści typu tej o życiu pierwszych chrześcijan”; „,chciałabym, aby były tematy o niektórych świętych np. o Ojcu Pio, Franciszku z Asyżu”; ,brakuje mi ciekawych opowiadań związanych z naszym życiem codziennym, rodzinnym, uczuciowym”; ,chce, aby były poruszane tematy o naszych uczuciach, emocjach”; „żeby na katechezie było więcej tematów o miłości”; „chciałabym, aby na lekcji były poruszane tematy związane z dojrzewaniem młodego człowieka, jego emocjami, wiarą; „brakuje ćwiczeń do samodzielnej pracy”; „brakuje mi takich rzeczy, które na naszym poziomie są zrozumiałe i dochodzą do odbiorcy”; „chciałbym, żeby były poruszane ciekawe tematy i łatwe"; „są rzeczy, których nie musi być, a tych, których my chcemy, to nie ma”.

Wydaje się więc konieczne przepracowanie treści podręcznika, jak i doboru metod, by podręcznik mógł być pomocą na tym ważnym etapie rozwoju gimnazjalistów. Przerasta on możliwości odbioru młodych ludzi. Młodzież szybciej przyswaja wiedzę, związaną z ich problemami, niż dotyczącą zagadnień ogólnych.

Często doświadczeniom katechetów w szkole towarzyszą porażki, gdyż prawdy okazują się za trudne do przyswojenia przez młodzież, a oni, na bieżąco nie są w stanie tworzyć nowych scenariuszy spotkań adekwatnych do wieku i możliwości uczniów.

\section{Metody aktywizujące pomocne w przyswajaniu wartości}

Doświadczenie nasze i wiedza tych, którzy zgłębiają podobne problemy pokazuje, iż jedynie mówienie o wartościach nie jest odpowiednią formą nauczania na

${ }^{10}$ KL. I Przyjąć blask Bożej prawdy; K1. II Wolni przez miłość; K1. III Żyjąc z innymi dla innych. 
poziomie gimnazjum. W poznawaniu wartości konieczne są przykłady, a pomocne mogą stać się następujące metody: dylematu moralnego, analizy przypadku, dramy, piramidy priorytetów.

W tych metodach mających na celu odkrywanie wartości, nie można manipulować odpowiedziami uczniów, nie można wmawiać, nie należy podawać gotowych rozwiązań. Należy uczyć poszukiwania i pozwolić zasmakować w trudzie szukania wartości.

\section{Metoda dylematu moralnego}

Celem tej metody jest uczenie aktywnego słuchania, argumentowania, umiejętnego opierania się na wartościach, przewidywania i liczenia się z konsekwencjami podjętych decyzji. Punktem wyjścia jest przedstawienie sytuacji problemowej, którą można przeczytać, opowiedzieć lub wyemitować film i przerwać w momencie podjęcia trudnej decyzji. Następnie uczniowie w grupach próbują rozwiązać tę sytuację, a po podjęciu decyzji odpowiadają na trzy punkty:

1. Najmocniejszy argument za wybranym rozwiązaniem.

2. Inne motywacje (wartości) przemawiające za podjęciem takiej decyzji.

3. Możliwe przykre konsekwencje takiego wyboru.

Po prezentacji grup ważne jest, aby dać uczniom czas na refleksję:

- Na ile po tych uzasadnieniach utwierdziło się moje stanowisko w tej sprawie?

- Czy nie zostałem przekonany argumentami innej grupy do zmiany decyzji?

Dokładna analiza wybranych rozwiązań przez uczniów i podawanych motywacji podczas zajęć metodą dylematu moralnego, służy do określenia konkretnego poziomu rozwoju moralnego danej grupy.

\section{Metoda analizy przypadku}

Cel: refleksja nad przeżywanymi problemami i pomoc w podjęciu bardziej świadomej decyzji

Schemat pracy:

1. Nazwanie problemu. 2. Pozytywy trudnej sytuacji. 3. Możliwe przyczyny zaistnienia problemu. 4. Możliwe rozwiązania. 5. Konsekwencje każdego rozwiązania. 6. Moje rozwiązanie (podjęta decyzja). 7. Motywacja (dlaczego tak, a nie inaczej). 8. Znaki potwierdzające słuszność wyboru.

\section{Metody dramy}

Metody dramowe to inaczej pewne techniki teatralne wykorzystane do celów edukacyjnych. Ich celem nie jest jednak sama gra, ale zrozumienie motywów, jakimi kierują się ludzie w postępowaniu. Łatwiej pomagają zrozumieć rzeczywistość. Służą one indywidualnemu, osobowemu rozwojowi. 
Punktem wyjścia pracy z wykorzystaniem metod dramowych jest zawsze określona sytuacja. Jest w niej zawarte napięcie, jakiś problem. Może to być sytuacja wzięta z życia, zaczerpnięta $\mathrm{z}$ fragmentu biblijnego lub wyobrażona. Bohaterami takiej sytuacji mogą być na przykład postacie obecne w tekście biblijnym, jak i spoza tekstu.

Sytuacja wyjściowa w dramie ma zawsze charakter otwarty. Nie ma gotowego scenariusza dalszego rozwoju sytuacji, który trzeba odegrać. To grupa lub uczeń tworzą scenariusz, własną wersję dalszego biegu wydarzeń. I tę własną wersję rozwoju wydarzeń przedstawiają na forum ogólnym wykorzystując różne techniki dramowe. Uczniowie mają w ten sposób możliwość podjęcia działań według własnego pomysłu. Stają się bardzo wyraźnie sprawcami działań. W tworzeniu scenariusza i w momencie prezentacji jest bardzo wyraźny moment improwizacji. Improwizacja ta musi jednak opierać się na wiedzy o sytuacji wyjściowej i o jej kontekście.

$\mathrm{W}$ pracy wykorzystującej metody dramowe nie ma przedstawienia w sensie klasycznym. Nie ma też podziału na aktora i widza. Wszyscy biorą udział w przygotowaniach i prezentacji. Poprzez właściwie prowadzoną rozmowę można pobudzić refleksję uczestników nad przedstawianymi sytuacjami, sprowokować ich do odkrywania prawdy o życiu.

Spośród metod dramy możemy wyliczyć na przykład:

- list - istotą tej metody jest napisanie przez uczestników listu „w imieniu” określonej postaci w związku z konkretnym wydarzeniem. Potrzebne materiały to papier, flamastry, klej, szary papier, ksero tekstu opisującego sytuację wyjściową;

- scenka improwizowana - istotą tej metody jest scenka przedstawiającą dalszy rozwój sytuacji wyjściowej według scenariusza przygotowanego przez grupy uczniów. Sytuacja ta musi być w jakiś sposób problematyczna i zawierać napięcie umożliwiające postawienie pytania - jak te wydarzenia mogłyby się potoczyć dalej?;

- rzeźba indywidualna i grupowa - istotą tej metody jest wyrażenie przeżyć i postawy danej osoby w związku z konkretnym wydarzeniem. Środkiem wyrazu jest ciało, gest, mimika „zastygłe” w nieruchomej rzeźbie. Materiałem do utworzenia rzeźby są sami uczestnicy. Rzeźba może być indywidualna lub grupowa.

\section{Metoda piramidy priorytetów (diagram diamentowy)}

Piramida priorytetów jest metodą hierarchizacji wypracowanego wcześniej materiału. Wypracowany materiał jest dziełem samej grupy (można tu stosować różne metody twórczego myślenia i dyskusji) albo zostaje dostarczony przez prowadzącego. Najczęściej ma on postać listy (różnych cech, potrzeb, części składowych, etapów itd.) sporządzonej bez troski o hierarchię ważności. Metoda wymaga od uczestników podejmowania decyzji wyboru „najważniejszych spośród ważnych” (co nie jest łatwe) a następnie decydowania o sposobie ich ułożenia. Piramida priorytetów wymaga umiejętności negocjacji - grupa ma wypracować pewien konsensus a nie zakrzyczeć czy przegłosować mniejszość. 


\section{Schemat pracy:}

Prowadzący dokonuje podziału na kilkuosobowe grupy. Uczestnicy wypracowują lub otrzymują gotową listę różnych cech, potrzeb, części, elementów związanych z omawianym tematem. Pierwszym ich zadaniem jest wybór z podanej listy 10 punktów ich zdaniem najważniejszych. Chodzi na tym etapie o rozmowę w grupie, wzajemne przekonywanie się i negocjacje. Należy wprowadzić zasadę, że nie wolno odmiennego zdania zakrzyczeć - należy używać rzeczowych argumentów a ewentualne głosowanie przeprowadzić jako ostateczność. Następnie wybrane punkty powinny zostać przepisane na małe karteczki. Grupa podejmuje rozmowę (w tym samym duchu, co poprzednio) nad sposobem ułożenia karteczek w piramidę - cztery karteczki w pierwszej warstwie, trzy w drugiej, dwie w trzeciej i na szczycie jedna.

\section{Podsumowanie}

Okres dorastania jest czasem nie tylko dojrzewania biologicznego, psychicznego, ale także czasem zetknięcia się ze światem wartości. Wartości wybierane i akceptowane przez dorastającego człowieka są w dużej mierze wyznacznikami jego zachowań i siłą motywującą do podjęcia określonego działania. Proces przyjmowania przez młodego człowieka wartości rozpoczyna się od spotkania z wartościa, poznania jej i tworzenia własnej hierarchii wartości. To wybrane przez niego wartości staną się drogowskazami w życiu. Stąd niezmiernie ważny jest proces poznawania istniejących wartości.

Znajomość wieku dorastania i stadiów rozwoju moralnego pomagają lepiej zrozumieć możliwości gimnazjalistów w odkrywaniu świata wartości. Tworzenie przez nich własnej hierarchii wartości wymaga od katechety umiejętności stosowania metod aktywizujących, pomocnych w przyswajaniu wartości. Trudne jest zadanie katechety. Ważne jest by chciał towarzyszyć młodym ludziom w dorastaniu. Nie powinien też oczekiwać szybkich i efektownych zmian w postępowaniu młodych ludzi. Sukces i porażka są wpisane w życie katechety.

\section{The discovery of values by middle school students - Catechism notes (Summary)}

The growing up period is usually not only a time of biological or mental growing but also a time of clash with the world of values. Chosen and accepted values by a grown-up are, to the large extent, determinants of his behavior, and a force motivating to taking up challenges. Whole process of getting values begins when a person meets a value on his way, gets to know it and then puts it in his own hierarchy of values. Chosen values will become guide posts in person's life. It is why, the process of getting to know all the values, is so important.

Danuta Jackowiak and ks. Jan Szpet, authors of a book for middle school students, propose showing the world of values by definitions, philosophical thoughts, pictures from life and nature. Nevertheless the book is quite difficult to be understood by middle school students. It is 
difficult to get to know what a value is only by reading definitions. We can also notice the lack of examples taken from our lives and methods which would easily help students to receive information. Moral dilemma, cases analysis, pyramid of priorities can help because they do not give clear solutions but teach how to seek them.

There is a difficult task for religion teachers who work in middle schools. From one point of view they are aware of the importance of showing students the world of values, on the other hand they have to find the right method which will help students understand them. It is important to be with students during their growing-up. You can't expect quick and effective changes in their behavior. Success and failure is what a religion teacher has to face. 